\title{
Determination of Groundwater Using Geoelectric Methods: Schlumberger Configuration in Rokan Hulu Regency
}

\author{
Yeza Febriani*1, Riza Ari Rohman², Azmi Azra ${ }^{3}$, Mohammad Apriniyadi ${ }^{4}$, Donata Nariswari \\ Wahyu Wardani ${ }^{5}$
}
1, 2, 3 Physics Study Programme, Faculty of teacher training and education, Pasir Pengaraian University, Rokan Hulu Regency 28557, Riau Province, Indonesia;
${ }^{4}$ Geology Technic Programme, Universitas Trisakti, Jakarta Barat, Jakarta, Indonesia;
${ }^{5}$ Groundwater management Programme, Faculty of Geoscience, Geoengineering and Mining, Freiberg University of Mining and Technology, Akademiestraße 609599 Freiberg, Germany.

*Corresponding Address: yezafebriani@upp.ac.id

\begin{tabular}{|c|c|}
\hline Article Info & ABSTRACT \\
\hline Article history: & This study aimed at detecting the presence of groundwater in Masda \\
\hline $\begin{array}{l}\text { Received: April }{ }^{\text {st }}, 2019 \\
\text { Accepted: October } 20^{\text {th }}, 2019 \\
\text { Published: October } 30^{\text {th }}, 2019\end{array}$ & $\begin{array}{l}\text { Makmur Village, Rambah Samo District, Rokan Hulu Regency, using the } \\
\text { Schlumberger configuration geoelectric method. The study consisted of } 3 \\
\text { sounding points within every } 100 \mathrm{~m} \text { sounding track length. The } \\
\text { measurement data is processed using IP2WIN software and Progress to see }\end{array}$ \\
\hline $\begin{array}{l}\text { Keywords: } \\
\text { aquifer; } \\
\text { geoelectric; } \\
\text { groundwater; } \\
\text { resistivity; } \\
\text { schlumberger. }\end{array}$ & $\begin{array}{l}\text { ayer data below the ground level based on the value of the resistivity type. } \\
\text { The results showed that the estimated groundwater could be found on track } \\
\text { one with a kind of resistivity value of } 7,44 \Omega \mathrm{m} \text { at a depth of } 15-22 \mathrm{~m} \text {. } \\
\text { Alleged groundwater can be found on the second track with a type of } \\
\text { resistivity value of } 75,73 \Omega \text { mat a depth of } 13-18 \mathrm{~m} \text {, and the estimated } \\
\text { groundwater can be located on the third track with a kind of resistivity value } \\
\text { of } 82,52 \Omega \mathrm{m}, 93,26 \Omega \mathrm{m} \text {. The deeper and the lower resistivity value shows } \\
\text { that the layer has the potential as a carrier layer of groundwater (aquifer). } \\
\text { Sounding } 1 \text { and } 2 \text { have the potential to make bore wells which are thought to } \\
\text { be depressed aquifer. The results of this study can be used further for } \\
\text { mapping the location of community boreholes }\end{array}$ \\
\hline
\end{tabular}

(C) 2019 Physics Education Department, UIN Raden Intan Lampung, Indonesia.

\section{INTRODUCTION}

Water is essential for life on earth (Saranga et al., 2016). Water consists of two atoms of hydrogen and one atom of oxygen $\left(\mathrm{H}_{2} \mathrm{O}\right)$. Living things cannot live without water. The increasing population requires a sufficient amount of water. In Indonesia, especially Rokan Hulu Regency, population growth is increasing every year (Bappeda Rokan Hulu, 2015).

In 2016, the percentage of population growth rate in the Rokan Hulu Regency was $0.27 \%, 2017$ experienced an increase of $0.09 \%$, and in 2018 there was an increase of
0.05\%. For Rambah Samo District, Rokan Hulu Regency in 2016 the population growth rate was $1,36 \%, 2017$ increased by $1,82 \%$ and in 2018 again experienced a significant increase of $2,05 \%$ (BPS Rokan Hulu, 2017). The higher of the population growth rate, the more need for clean water by the community. Groundwater is one source of life necessities for living things on earth (Hanifa, Sota, \& Siregar, 2016; Sehah \& Aziz, 2016). Groundwater is all water found in layers containing water (aquifers) below the surface of the soil. The role of groundwater is increasingly essential to 
become the primary water source to fulfill the basic needs of many people (Jusuf, 2015; Sedana, As'ari, \& Tanauma, 2015).

Specific methods can detect the presence of groundwater in the subsurface layer (Devi, Israil, Anbalagan, \& Gupta, 2017; Heradian \& Arman, 2015; Wijaya, 2015). One of which is by using the geoelectric resistivity method. This method is the most popular method of investigating groundwater from the surface of the earth (Bakri, 2019; Bashir, Izham, \& Main, 2014; El-Hameed, El-Shayeb, El-Araby, \& Hegab, 2017; Helaly, 2017; Hewaidy et al., 2015; Jusuf, 2015; Mohamaden, 2016). The geoelectric method is a method that studies the nature of electricity on the planet by detecting it on the earth's surface (Hakim \& Manrulu, 2017).

Several studies on the detection of groundwater estimation using Schlumberger configuration have been carried out, including editions (Edisar, 2013) of data obtained, namely zoning of free aquifers and depressed aquifers. Sehah and Azis (Sehah \& Aziz, 2016) obtained resistivity data that represents the type of subsurface rock shallow aquifer layer estimated to be composed of fine-grained sand $(0.85 \Omega \mathrm{m})$ and sandy clay $(13.25 \Omega \mathrm{m})$ with a depth between 7.35-29.44 m.

From various studies that have been carried out, information about aquifer layers in Riau province is still very limited, aquifer mapping is only carried out in the area around city of Pekanbaru (Alfadli et al., 2017; Parhusip \& Syech, 2013), while information on the location of aquifers is also needed in other districts in Riau Province, one of them is Rokan Hulu District. This district is one of the twelve districts in the city in Riau Province. Some clean water facilities in this district do not operate optimally because the source of water used is based on wells. Water from the wellbore is no longer flowing because the determination of the drilling location is only an estimate and is not well planned. With this problem, information about the area of the aquifer is needed.

Masda Makmur village is one of the communities located in Rambah Samo District, Rokan Hulu Regency. This village is located not far from the river, but during the dry season, the village often experiences drought. Most of the residents use rain-fed wells as water reserves for their daily needs. This is indeed not effective, because, in the end, these wells will experience drought during the dry season. To be able to minimize dryness during the dry season, local people can use groundwater sources. But until now, no research has been carried out to detect the presence of groundwater in this area.

\section{METHODS}

The research was conducted in Masda Makmur Village, Rokan Hulu Regency. The tool used in this research is resistivity meter Georesist RS505, GPS, and Laptop. The tools used in processing data are Progress and IP2WIN software.

The geological map of the research area is shown in Figures 1 and 2. The geological setting is divided into many stratigraphic components (Sihapas Formation Formation, Farmer Formation, Alluvium, and Minas Formation). The hydrological characteristics of Rokan Hulu are shown by several rivers flowing from the peak of Suligi or from the east to the hills towards the West.

The research area was around the river. The river flowing in Rokan Hulu consists of two types of streams, the river flowing through Rokan Hulu and the river flowing only in Rokan Hulu alone. The method used in this study is the resistivity geoelectric method using the Schlumberger configuration. 


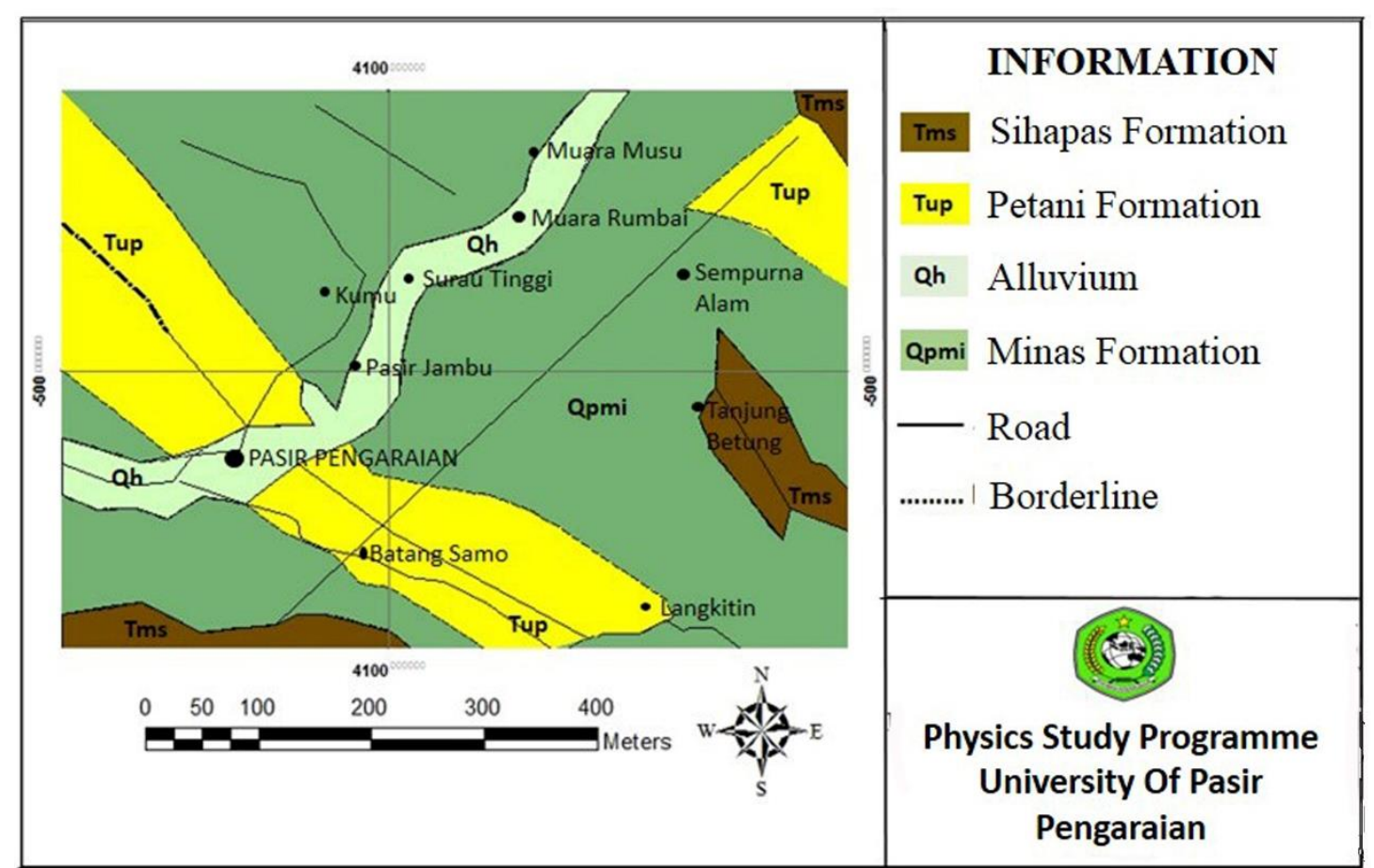

Figure 1. Geological Map of the Research Area

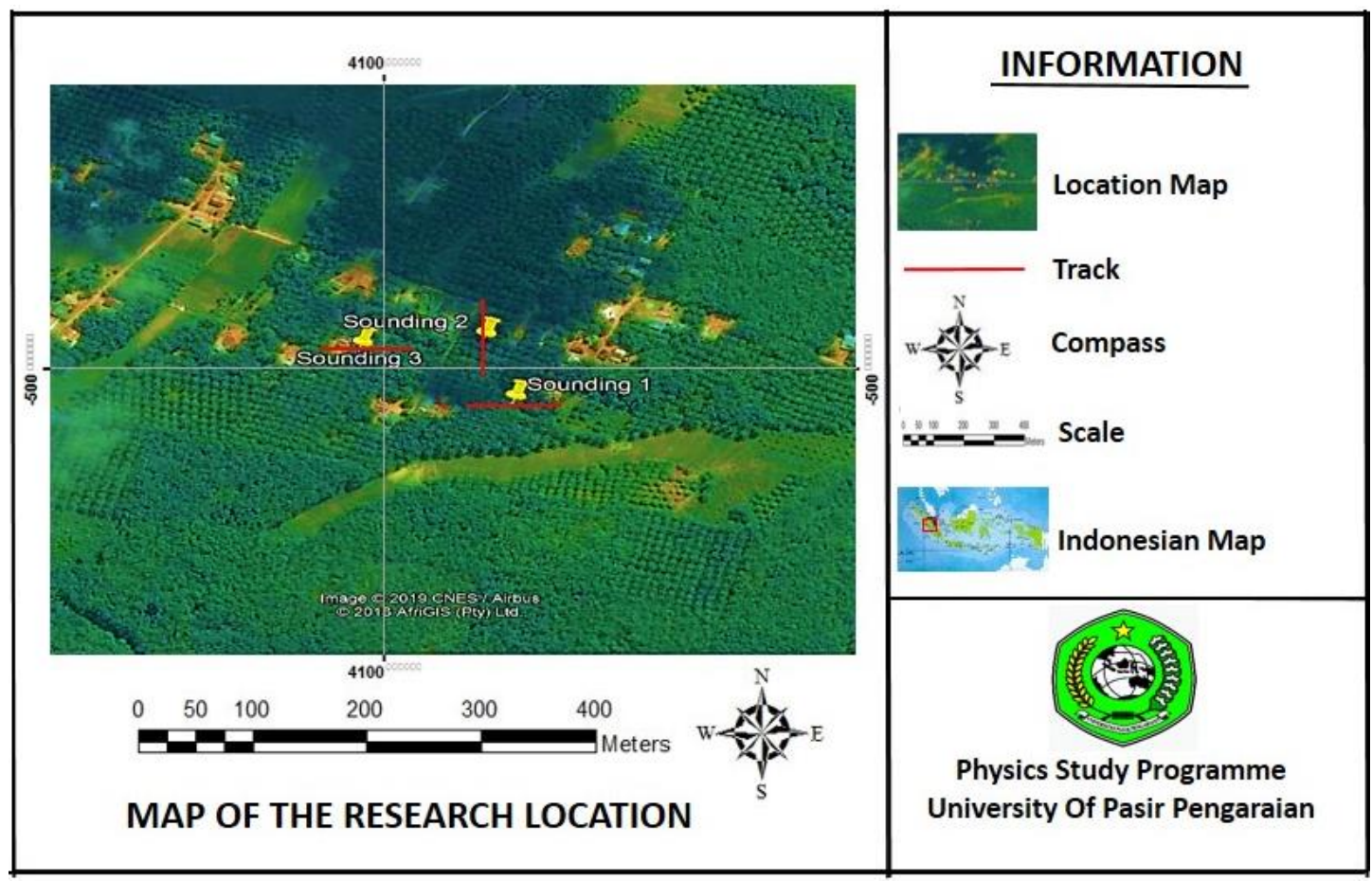

Figure 2. Map Based on The Points Electrodes

The resistivity geoelectric method is still the most powerful technique and costeffective in the investigation of groundwater (Mahmoud \& Kotb, 2017). All types of resistivity measurements are seeking to track changes in resistivity values vertically and horizontally (Bashir et al., 2014; Kumar, 2015; Mahmoud \& Kotb, 2017).

This method consists of electric current between two electrodes injected through the ground, and then induction between two potential electrodes produces a potential difference (Claude, Théophile, Patrick, \& 
Crepin, 2014; Tijani, Osinowo, \& Ogedengbe, 2009). The geoelectric data collection location map based on the points of the electrodes which are formed which form several lines (Figure 2. Map of Research).

The electrode arrangement in the Schlumberger configuration can be seen in Figure 3. The type of material can be known based on the resistivity value of the structure in each layer presented in table 1 .

From Figure 3 above, the apparent resistivity equation for this configuration is formulated as (Fitrianto, Taufiq, \& Mukromin, 2018):

$\rho_{a}=K \frac{\Delta V}{I}$

With $\rho$ a is pseudo resistivity $(\Omega \mathrm{m}), K$ is a geometry factor, $\Delta \mathrm{V}$ is a potential difference (Volt), and I is the amount of current (ampere).

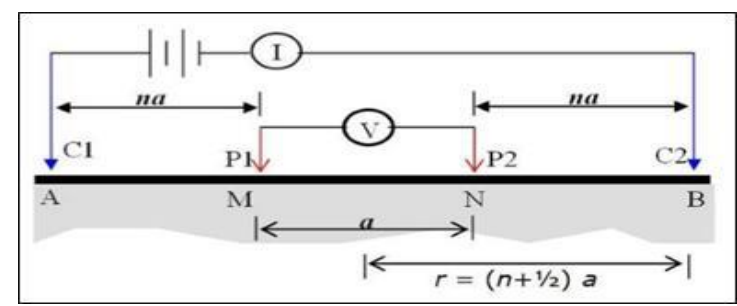

Figure 3. Arrangement of Electrodes in Schlumberger Configuration

Table 1. The Resistivity of Material (Febriani and Sohibun, 2019)

\begin{tabular}{l|r}
\hline \hline Material & \multicolumn{1}{|l}{$\begin{array}{l}\text { Resistivity } \\
(\Omega \mathrm{m})\end{array}$} \\
\hline Igneous and Metamorphic & $5 \times 10^{3}-10^{6}$ \\
Rocks & $10^{3}-10^{6}$ \\
Granite & $6 \times 10^{2}-4 \times 10^{7}$ \\
Basalt & $10^{2}-2,5 \times 10^{8}$ \\
Slate & $10^{2}-2 \times 10^{8}$ \\
Marble & $50-4 \times 10^{2}$ \\
Quartzite & \\
Sedimentary Rocks & $8-4 \times 10^{3}$ \\
Sandstone & $20-2 \times 10^{3}$ \\
Shale & $50-4 \times 10^{2}$ \\
Limestone & \\
Soils and water & $1-100$ \\
Clay & $10-800$ \\
Alluvium & $10-100$ \\
Groundwater & 0,2 \\
Seawater &
\end{tabular}

\section{RESULTS AND DISCUSSION Sounding 1}

On sounding 1 , the track length is 100 meters. This track is located at 0054' 34 'E and $100023^{\prime} 44^{\prime} \mathrm{N}$. The interpretation results on track one is shown in Figure 4 and 7(a) with an RMS error of $9,08 \%$.

In the first layer with a depth of $0-0,5 \mathrm{~m}$, the resistivity value is $79,90 \Omega \mathrm{m}$. This type of resistivity value is interpreted as a surface groundwater layer which is thought to originate from rainwater infiltration (Bakri, 2019). At a depth of 0,5-3 $\mathrm{m}$ has a resistivity value of $154,69 \Omega \mathrm{m}$. This type of resistivity value is associated with alluvium. The kind of resistivity value is above 100 $\Omega \mathrm{m}$.

The resistance value of this type is higher than the value of the previous resistance (Febriani \& Sohibun, 2019). Presumably, this layer is the gravel layer. At depths of 3 $-8,5 \mathrm{~m}$ have a more significant value of resistivity of $1535,27 \Omega \mathrm{m}$. This high type of resistivity value is assumed to be a sandstone layer. This layer does not contain groundwater. At a depth of 8,5-15 m has a resistivity value of $154,91 \mathrm{~m}$. This type of resistance value is thought to be a layer of gravel (Bakri, 2019) and at a depth of 15-22 $\mathrm{m}$ has a low resistance value of $7,44 \Omega \mathrm{m}$.

The value of this type of low resistivity is associated with groundwater, namely (1$100 \Omega \mathrm{m}$ ). According to Wijaya (Wijaya, 2015), the value of detainees of types less than $(10 \Omega \mathrm{m})$ is assumed to be groundwater that has poor quality. Seen conditions in the field, there is a pile of garbage that is thought to reduce the quality of the groundwater.

\section{Sounding 2}

On sounding 2, the track length is 100 meters. This track is located at coordinates 0054' 37" E and 100023'43" N. The results of the interpretation on the second track with RMS error 7,65\% have different layer variations shown in Figures5 and 7 (b). In the first layer, with a depth of $0-0,5 \mathrm{~m}$ has a resistivity value of $20,59 \Omega \mathrm{m}$. 
This type of resistivity value is interpreted as a surface groundwater layer which is thought to originate from rainwater infiltration (Bakri, 2019). At a depth of 0,5 $3 \mathrm{~m}$ has a resistance value of $449,86 \Omega \mathrm{m}$. Alleged rock in this layer is gravel (Febriani $\&$ Sohibun, 2019). At a depth of 3,5-13 m has a higher resistance value than the previous layer, which is $2874,68 \Omega \mathrm{m}$. This type of resistivity value can be interpreted as a layer of sandstone that has no potential for groundwater.

At a depth of approximately 13-18 m, the value of the resistivity is lower, which is $75,73 \mathrm{~m}$. This layer is supposed to be a layer of sand that can escape and store water. This type of resistivity value is assumed to be potential groundwater because at this depth the layer thickness is up to 5 meters (Febriani \& Sohibun, 2019).
The length of the third tracks stretches with a length of 100 meters with a distance between electrodes of 0,5 meters. This track is located in coordinates 0054'36" $\mathrm{E}$, and $100023^{\prime} 40^{\prime \prime} \mathrm{N}$. The interpretation of the three tracks with 4,3\% RMS errors have different layer variations (Figures 6 and 7 (c)).

In the first, second, and third layers, it has a resistivity value of $183 \Omega \mathrm{m}, 377,27$ $\Omega \mathrm{m}$, and $687,34 \Omega \mathrm{m}$. These three layers are thought to be non-aqueous layers because they have resistivity values of more than $100 \mu \mathrm{m}$ (Febriani \& Sohibun, 2019). From a depth of 7,5-28 m, the type of resistivity value between 42-93,26 $\Omega \mathrm{m}$ can be interpreted as one variation of the layer, namely the sand layer with a layer thickness of up to $20 \mathrm{~m}$. The depth of this layer can be assumed as potential groundwater (Bakri, 2019).

\section{Sounding 3}




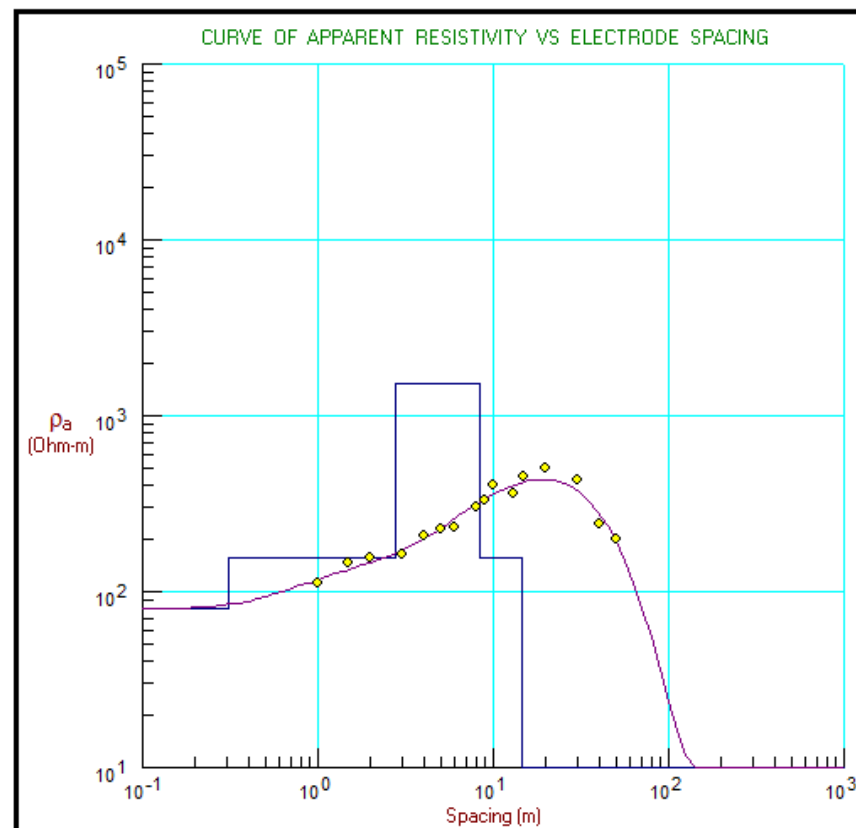

TABLE OF INTERPRETED DATA

\begin{tabular}{|c|c|c|c|c|}
\hline No. & Spacing (m) & Observed Data (0hm-m) & Calculated Data $(0 \mathrm{hm}-\mathrm{m})$ & Error $[\%]$ \\
\hline 1 & 1.00 & 112.630 & 117.382 & 4.2193 \\
\hline 2 & 1.50 & 145.588 & 133.848 & -8.0641 \\
\hline 3 & 2.00 & 156.925 & 146.794 & -6.4557 \\
\hline 4 & 3.00 & 161.742 & 171.681 & 6.1447 \\
\hline 5 & 4.00 & 209.774 & 199.327 & -4.9798 \\
\hline 6 & 5.00 & 225.750 & 229.037 & 1.4559 \\
\hline 7 & 6.00 & 231.392 & 258.857 & 11.8693 \\
\hline 8 & 8.00 & 304.504 & 313.462 & 2.9417 \\
\hline 9 & 9.00 & 330.938 & 336.984 & 1.8269 \\
\hline 10 & 10.00 & 403.676 & 357.719 & -11.3846 \\
\hline 11 & 13.00 & 362.509 & 403.703 & 11.3636 \\
\hline 12 & 15.00 & 454.843 & 422.151 & .7 .1875 \\
\hline 13 & 20.00 & 509.000 & 434.801 & .14 .5773 \\
\hline 14 & 30.00 & 432.801 & 375.556 & .13 .2266 \\
\hline 15 & 40.00 & 240.577 & 280.463 & 16.5794 \\
\hline 16 & 50.00 & 199.016 & 193.708 & -2.6669 \\
\hline 17 & & & & \\
\hline 18 & & & & \\
\hline 19 & & & & \\
\hline 20 & & & & \\
\hline 21 & & & & \\
\hline 22 & & & & \\
\hline 23 & & & & \\
\hline 24 & & & & \\
\hline 25 & & & & \\
\hline 26 & & & & \\
\hline 27 & & & & \\
\hline 28 & & & & \\
\hline 29 & & & & \\
\hline 30 & & & & \\
\hline 31 & & & & \\
\hline 32 & & & & \\
\hline 33 & & & & \\
\hline 34 & & & & \\
\hline 35 & & & & \\
\hline
\end{tabular}

Sounding Point : Masda L1

Electrode Configuration : Schlumberger

RiMS (Root Mean Square) : $9.0894 \%$

\begin{tabular}{|r|r|r|}
\hline \multicolumn{3}{|c|}{ Model Parameters } \\
\hline 1 & Depth & Resistivity \\
\hline 2 & 0.00 & 79.90 \\
3 & 2.71 & 156.69 \\
4 & 8.29 & 1535.27 \\
5 & 14.71 & 154.91 \\
6 & & 7.44 \\
7 & & \\
8 & & \\
9 & & \\
10 & & \\
11 & & \\
12 & & \\
\hline
\end{tabular}

Description

$\therefore \quad=$ Observed Data

$=$ Calculated Data

$\square-\sqrt{ }=$ Model Parameters

$\rho_{\mathrm{a}} \quad=$ Apparent Resistivity $[0 \mathrm{hm}-\mathrm{m})$

Spacing = Electrode Spacing (m): $\mathrm{AB} / 2$

Depth = Depth of Layer $(\mathrm{m})$

Resistivity $=$ True Resistivity of Layer $(0 \mathrm{hm}-\mathrm{m})$

Riesitivity Log

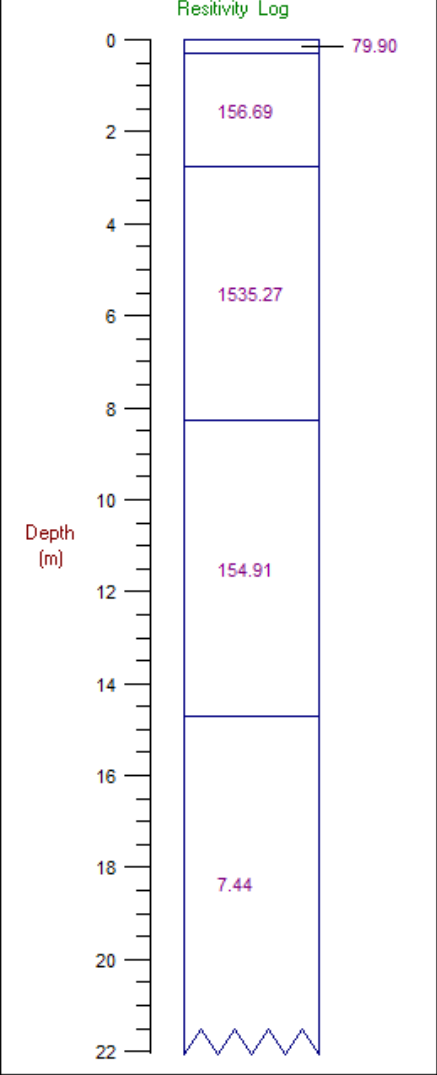

Figure 4. Results of Data Processing Resistivity to Depth on Sounding 1 


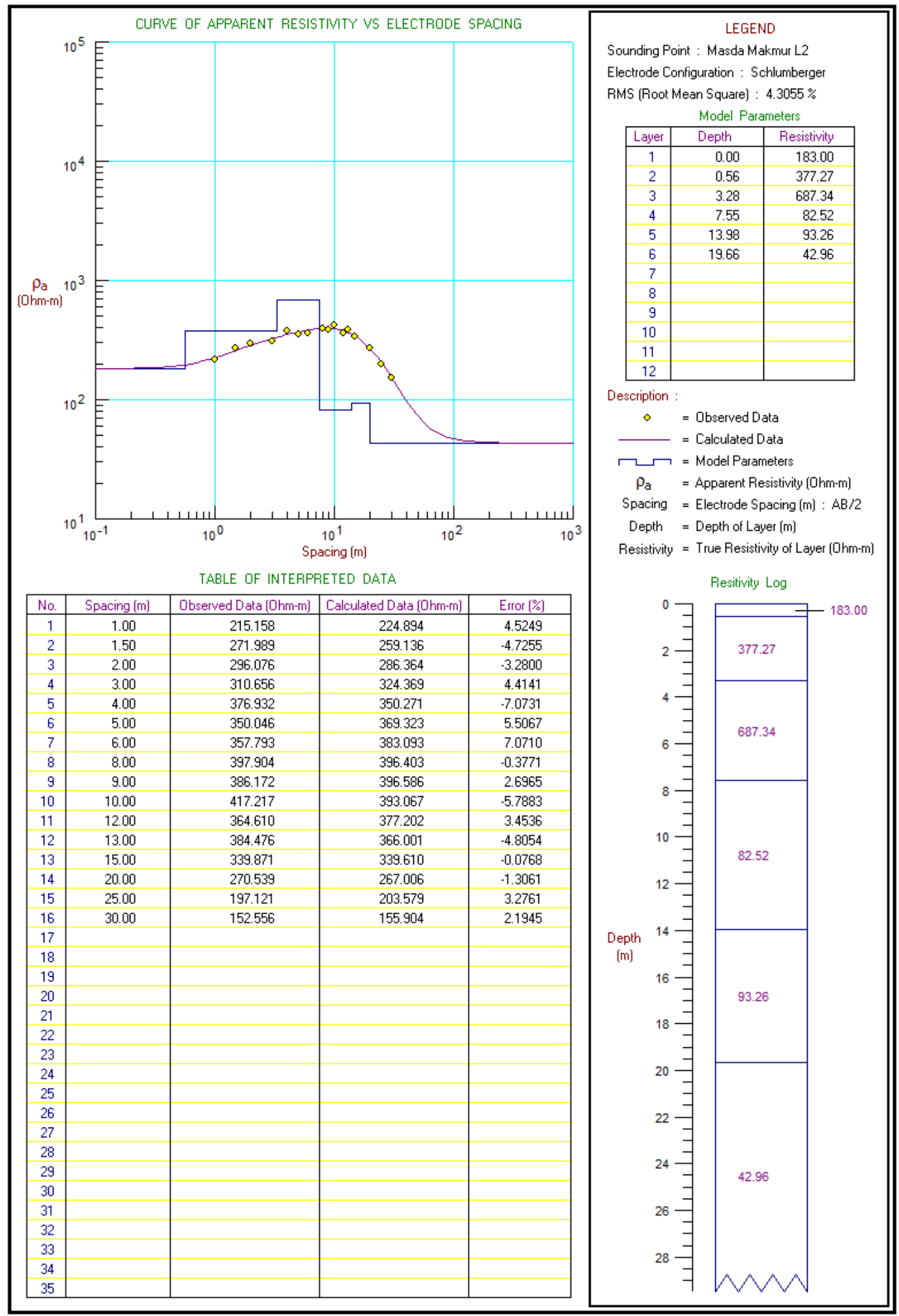

Figure 5. Results of Data Processing Resistivity to Depth on Sounding 2 


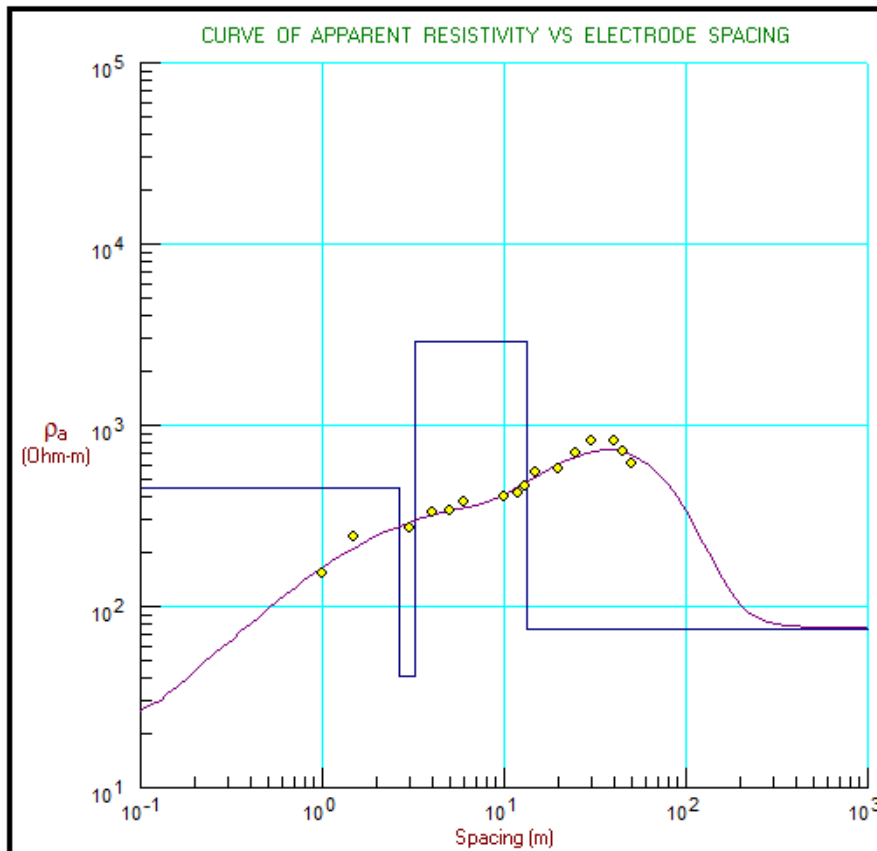

LEGEND
Sounding Point : L3 Masda

Electrode Configuration : Schlumberger

RMS (Root Mean Square) : $7.6549 \%$

\begin{tabular}{|r|r|r|}
\hline Layer & Depth & Resistivity \\
\hline 1 & 0.00 & 20.59 \\
2 & 0.09 & 449.86 \\
3 & 2.66 & 41.69 \\
4 & 3.19 & 2874.68 \\
\hline 5 & 13.24 & 75.73 \\
6 & & \\
7 & & \\
8 & & \\
9 & & \\
10 & & \\
11 & & \\
12 & & \\
\hline
\end{tabular}

Description :

$\circ \quad=$ Observed Data

= Calculated Data

$\square-\sqrt{\square}=$ Model Parameters

$\rho_{\mathrm{a}} \quad=$ Apparent Resistivity $[0 \mathrm{hm}-\mathrm{m})$

Spacing = Electrode Spacing (m) : $\mathrm{AB} / 2$

Depth = Depth of Layer $(\mathrm{m})$

Resistivity $=$ True Resistivity of Layer $[0 \mathrm{hm}-\mathrm{m})$

TABLE OF INTERPRETED DATA

\begin{tabular}{|c|c|c|c|c|}
\hline No. & Spacing (m) & Observed Data (Ohm-m) & Calculated Data (0hm-m) & Error $[\%]$ \\
\hline 1 & 1.00 & 152.896 & 163.446 & 6.8999 \\
\hline 2 & 1.50 & 243.332 & 211.431 & -13.1097 \\
\hline 3 & 3.00 & 272.299 & 292.569 & 7.4441 \\
\hline 4 & 4.00 & 328.025 & 318.705 & .2 .8413 \\
\hline 5 & 5.00 & 336.550 & 335.491 & -0.3145 \\
\hline 6 & 6.00 & 375.109 & 349.106 & -6.9321 \\
\hline 7 & 10.00 & 400.859 & 415.026 & 3.5342 \\
\hline 8 & 12.00 & 421.521 & 456.908 & 8.3950 \\
\hline 9 & 13.00 & 460.205 & 478.526 & 3.9811 \\
\hline 10 & 15.00 & 554.330 & 521.044 & -6.0047 \\
\hline 11 & 20.00 & 579.208 & 612.762 & 5.7932 \\
\hline 12 & 25.00 & 697.515 & 676.550 & .3 .0057 \\
\hline 13 & 30.00 & 817.452 & 713.799 & -12.6800 \\
\hline 14 & 40.00 & 816.015 & 727.004 & -10.9081 \\
\hline 15 & 45.00 & 722.618 & 711.858 & -1.4890 \\
\hline 16 & 50.00 & 612.875 & 687.183 & 12.1245 \\
\hline \multicolumn{5}{|l|}{17} \\
\hline \multicolumn{5}{|l|}{18} \\
\hline \multicolumn{5}{|l|}{19} \\
\hline \multicolumn{5}{|l|}{20} \\
\hline \multicolumn{5}{|l|}{21} \\
\hline \multicolumn{5}{|l|}{22} \\
\hline \multicolumn{5}{|l|}{23} \\
\hline \multicolumn{5}{|l|}{24} \\
\hline \multicolumn{5}{|l|}{25} \\
\hline \multicolumn{5}{|l|}{26} \\
\hline \multicolumn{5}{|l|}{27} \\
\hline \multicolumn{5}{|l|}{28} \\
\hline \multicolumn{5}{|l|}{29} \\
\hline \multicolumn{5}{|l|}{30} \\
\hline \multicolumn{5}{|l|}{31} \\
\hline \multicolumn{5}{|l|}{32} \\
\hline \multicolumn{5}{|l|}{33} \\
\hline 34 & & & & \\
\hline 35 & & & & \\
\hline
\end{tabular}

Resitivity Log

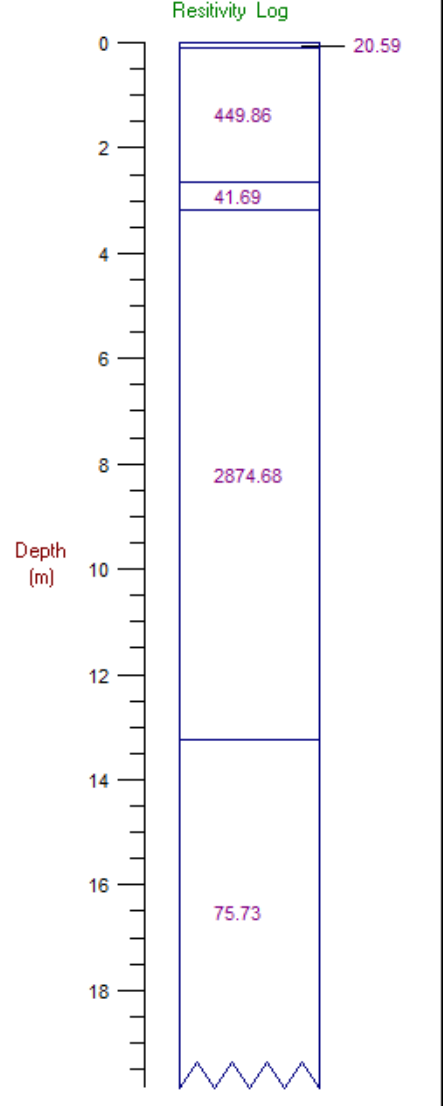

Figure 6. Results of Data Processing Resistivity to Depth on Sounding 3 


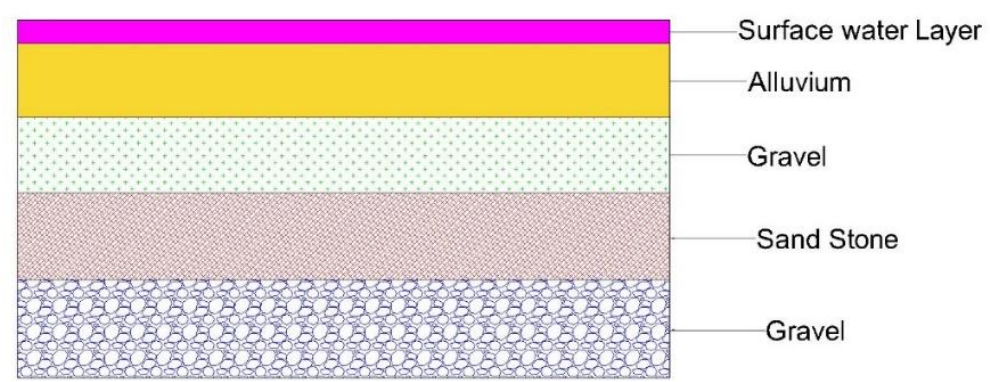

(a)

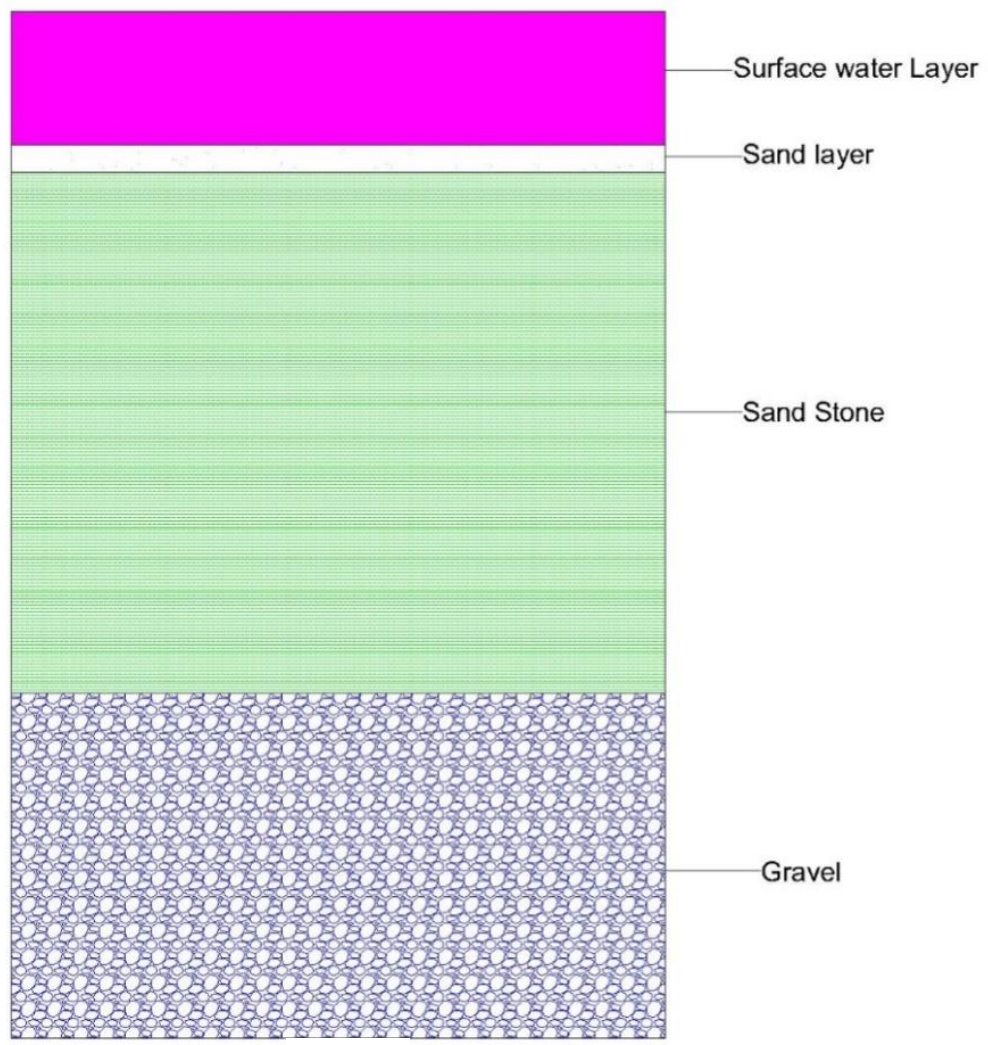

(b)

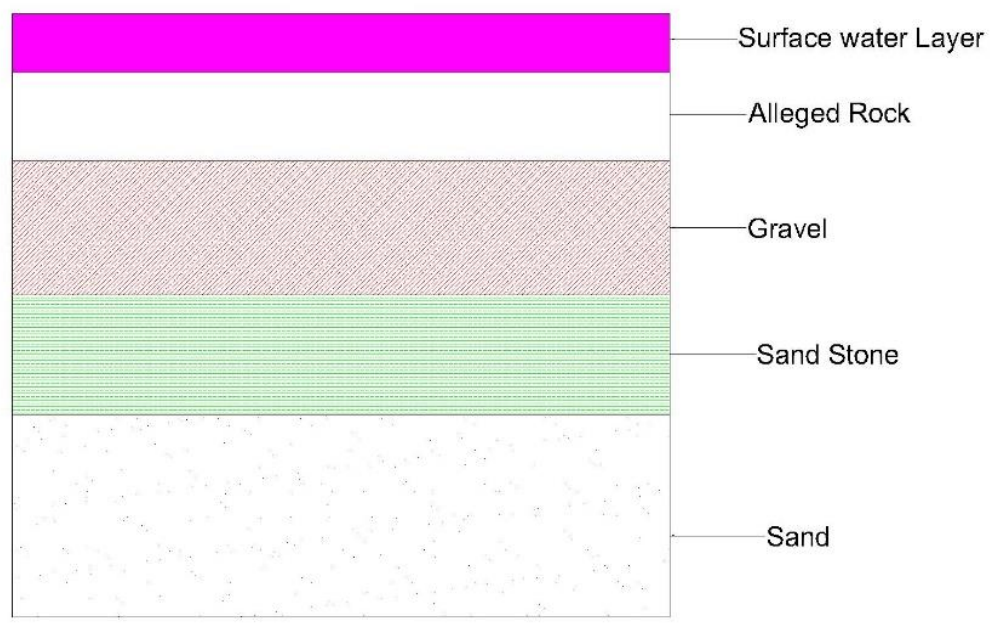

(c)

Figure 7.(a) 2D cross section sounding 1, (b) 2D cross section sounding 2, (c) 2D cross section sounding 3 


\section{CONCLUSION AND SUGGESTION}

Based on the results of the research, it can be concluded that the groundwater was found in all three soundings points with varying resistivity values ranging from 7 to $93.26 \Omega \mathrm{m}$. The type of constituent material is sand. The three sounding points have different layers of variation. The deeper resistivity value and the lower it shows that the layer has the potential as a carrier layer of groundwater (aquifer). Sounding 1 and 2 have the potential to make bore wells which are thought to be depressed aquifer while sounding three is believed to be a free aquifer. Information on aquifer layers that have been obtained from the research can be a reference for stakeholders and the community to map the location of drilling wells.

\section{AUTHOR CONTRIBUTIONS}

YF drafted and designed the research design. RA detects the presence of water and collects data. AA performs statistical calculations and generates results. MA conducts discussions. DN made edits.

\section{REFERENCES}

Alfadli, M. K., Mardiana, U., Hadian, M. S. D., Mohammad, F., Natasia, N., \& Imaduddin, M. (2017). Pemetaan Cekungan Airtanah Pekanbaru Menggunakan Data VES (Vertical Electrical Sounding), Provinsi Riau, Indonesia Pekanbaru Groundwater Basin Mapping Using VES (Vertical Electrical Sounding) Data, Riau Province, Indonesia. OSF Repository.

Bakri, H. (2019). Pendugaan Ketebalan Aquifer Air Tanah untuk Pengembangan Kawasan Sofifi Maluku Utara. Jurnal Geomine, 4(1), 5-10. https://doi.org/10.33536/jg.v4i1.37

Bashir, I. Y., Izham, M. Y., \& Main, R. (2014). Vertical Electrical Sounding Investigation of Aquifer Composition and it's Potential to Yield Groundwater in Some Selected Towns in Bida Basin of North Central Nigeria. Journal of
Geography and Geology, 6(1), 60-69. https://doi.org/10.5539/jgg.v6n1p60

Claude, N. P., Théophile, N.-M., Patrick, A. S., \& Crepin, K. T. (2014). Evidence of Iron Mineralization Channels in the Messondo Area (Centre-Cameroon) Using Geoelectrical (DC \& IP) Methods: A Case Study. International Journal of Geosciences, 05(03), 346361.

https://doi.org/10.4236/ijg.2014.53034

Devi, A., Israil, M., Anbalagan, R., \& Gupta, P. K. (2017). Subsurface Soil Characterization Using Geoelectrical and Geotechnical Investigations at a Bridge Site in Uttarakhand Himalayan Region. Journal of Applied Geophysics, 144, 78-85. https://doi.org/10.1016/j.jappgeo.2017. 07.005

Edisar, M. (2013). Pemetaan Zonasi Air Bawah Tanah di Kecamatan Pinggir Kabupaten Bengkalis Provinsi Riau. Prosiding SEMIRATA 2013, 405-408. Retrieved from http://jurnal.fmipa.unila.ac.id/index.ph $\mathrm{p} / \mathrm{semirata/article/view/767}$

El-Hameed, A. G. A., El-Shayeb, H. M., ElAraby, N. A., \& Hegab, M. G. (2017). Integrated Geoelectrical and Hydrogeological Studies on Wadi Qena, Egypt. NRIAG Journal of Astronomy and Geophysics, 6(1), 218229.

https://doi.org/10.1016/j.nrjag.2017.03. 003

Febriani, Y., \& Sohibun. (2019). Aplikasi Metode Geolistrik Konfigurasi Schlumberger untuk Mengidentifikasi Lapisan Air Tanah di Desa Ulak Patian Rokan Hulu Riau. Jurnal Fisika Flux, 16(1), 54-60.

Fitrianto, T. N., Supriyadi, S., Taufiq, U. A., Mukromin, T. M., \& Wardana, A. P. (2018). Identifikasi Potensi Air Tanah Menggunakan Metode Geolistrik Resistivitas Konfigurasi Schlumberger di Kelurahan Bapangsari Kecamatan Bagelen Kabupaten Purworejo. Jurnal 
Fisika Flux: Jurnal Ilmiah Fisika FMIPA Universitas Lambung Mangkurat. 15 (2), 100-104.

Hakim, H., \& Manrulu, R. H. (2017). Aplikasi Konfigurasi Wenner dalam Menganalisis Jenis Material Bawah Permukaan. Jurnal Ilmiah Pendidikan Fisika Al-Biruni, 5(1), 95. https://doi.org/10.24042/jpifalbiruni.v5 i1.109

Hanifa, D., Sota, I., \& Siregar, S. S. (2016). Penentuan Lapisan Akuifer Air Tanah dengan Metode Kalimantan Selatan. Jurnal Fisika Flux: Jurnal Ilmiah Fisika FMIPA Universitas Lambung Mangkurat. 13 (1) 30-39.

Helaly, A. S. (2017). Assessment of Groundwater Potentiality Using Geophysical Techniques in Wadi Allaqi Basin, Eastern Desert, Egypt Case Study. NRIAG Journal of Astronomy and Geophysics, 6(2), 408421.

https://doi.org/10.1016/j.nrjag.2017.09. 003

Heradian, E. A., \& Arman, Y. (2015). Pendugaan Bidang Gelincir Tanah Longsor di Desa Aruk Kecamatan Sajingan Besar Kabupaten Sambas dengan Menggunakan Metode Tahanan Jenis. III(2), 56-61.

Hewaidy, A. G. A., El-Motaal, E. A., Sultan, S. A., Ramdan, T. M., El khafif, A. A., \& Soliman, S. A. (2015). Groundwater Exploration using Resistivity and Magnetic Data at the Northwestern Part of the Gulf of Suez, Egypt. Egyptian Journal of Petroleum, 24(3), 255-263. https://doi.org/10.1016/j.ejpe.2015.07.0 10

Hulu, Bappeda Rokan. (2015). Program Percepatan Sanitasi Pemukiman (PPSP). Laporan Pokja Air Minum dan Penyehatan Lingkungan.

Hulu, BPS Rokan. (2017). Kabupaten Rokan Hulu dalam Angka. Laporan BPS Rokan Hulu, 14070.1702(1), 228.

Jusuf, A. S. (2015). Geologi dan Pemetaan
Cekungan Air Tanah Kota Gorontalo dengan Menggunakan Metode Geolistrik Tahanan Jenis. Jurnal Fakultas MIPA UNG.

Kumar, R. (2015). Geohydrological Investigation Using Vertical Electrical Sounding at Banaras Hindu University Campus, Varanasi, U.P, India. International Journal of Research in Engineering and Technology, 03(09), 252-256.

https://doi.org/10.15623/ijret.2014.030 9038

Mahmoud, H. H., \& Kotb, A. D. M. (2017). Impact of the Geological Structures on the Groundwater potential Using eophysical Techniques in West Bani Mazar area, El Minia - Western Desert, Egypt. Journal of African Earth Sciences, 130, 161-173. https://doi.org/10.1016/j.jafrearsci.2017 .03 .024

Mohamaden, M. I. I. (2016). Delineating Groundwater Aquifer and Subsurface Structures by Using Geoelectrical Data: Case Study (Dakhla Oasis, Egypt). NRIAG Journal of Astronomy and Geophysics, 5(1), 247-253. https://doi.org/10.1016/j.nrjag.2016.05. 001

Parhusip, M., \& Syech, R. (2013). Menentukan Akuifer Lapisan Air Tanah dengan Metode Geolistrik Konfigurasi Schlumberger di Perumahan Griyo Puspito dan Bumi Tampan Lestari. FMIPA Universitas Riau, 1-8.

Saranga, H. T., As'ari, \& Tongkukut, S. H. J. (2016). Deteksi Air Tanah Menggunakan Metode Geolistrik Resistivitas Konfigurasi WennerSchlumberger di Masjid Kampus Universitas Sam Ratulangi dan Sekitarnya. Jurnal Mipa Unsrat, 5(2), 70-75.

Sedana, D., As'ari, \& Tanauma, A. (2015). The Mapping of Groundwater Aquifers at the Ringroad Malendeng Village by Using Geoelectric Resistivity Method. 
Jurnal Ilmiah Sains, 15(2), 1-5.

Sehah, S., \& Aziz, A. N. (2016). Pendugaan Kedalaman Air Tanah Menggunakan Metode Geolistrik Konfigurasi Schlumberger di Desa Bojongsari, Kecamatan Alian, Kabupaten Kebumen. Jurnal Neutrino, 8(2), 41. https://doi.org/10.18860/neu.v8i2.3239 Tijani, M. N., Osinowo, O. O., \& Ogedengbe, O. (2009). Mapping of Sub-Surface Fracture Systems Using
Integrated Electrical Resistivity Profiling and VLF-EM Methods: A Case Study of Suspected Gold Mineralization. RMZ-Materials and Geoenvironment, 56(4), 415-436.

Wijaya, A. S. (2015). Aplikasi Metode Geolistrik Resistivitas Konfigurasi Wenner untuk Menentukan Struktur Tanah di Halaman Belakang SCC ITS Surabaya. Jurnal Fisika Indonesia, 19(55), 1-5. 